\title{
Genetic overlap and causal associations between smoking behaviours and psychiatric traits and disorders in adolescents and adults
}

Wikus Barkhuizen ${ }^{1,2}$, Frank Dudbridge ${ }^{3}$ and Angelica Ronald ${ }^{1}$.

Author affiliations:

1) Centre for Brain and Cognitive Development, Department of Psychological Sciences, Birkbeck, University of London, UK; 2) Department of Clinical, Educational and Health Psychology, University College London, London, UK; 3) Department of Health Sciences, University of Leicester, UK.

\section{Corresponding authors:}

Wikus Barkhuizen, Centre for Brain and Cognitive Development, Department of Psychological Sciences, Birkbeck, University of London, Malet Street, London WC1E 7HX, UK; email: w.barkhuizen@ucl.ac.uk

Angelica Ronald, Centre for Brain and Cognitive Development, Department of Psychological Sciences, Birkbeck, University of London, Malet Street, London WC1E 7HX, UK; tel: 44-20 7631 6342; email: a.ronald@bbk.ac.uk

Keywords: Tobacco; schizophrenia; depression; bipolar disorder; psychotic-like experiences; psychosis; Mendelian randomization; Genomic Structural Equation Modelling; ALSPAC 
medRxiv preprint doi: https://doi.org/10.1101/2020.02.07.20021089; this version posted February $9,2020$. The copyright holder for this preprint (which was not certified by peer review) is the author/funder, who has granted medRxiv a license to display the preprint in It is made available under a CC-BY-NC-ND 4.0 International license .

\begin{abstract}
Background: Epidemiological research shows that smoking is associated with psychiatric disorders and psychotic experiences, even after controlling for confounds such as cannabis use and sleep problems. We investigated degree of genetic overlap and tested for causal associations between smoking and psychiatric traits and disorders using genetic data. We tested whether genetic associations existed beyond genetic influences shared with confounding variables.
\end{abstract}

Methods: Genetic correlations were estimated with LD-score regression between smoking behaviours ( $\mathrm{N}=262,990-632,802)$ and psychiatric disorders (schizophrenia, bipolar disorder and depression; $\mathrm{N}=41,653-173,005)$, psychotic experiences in adolescents $(\mathrm{N}=6,297-10,098)$ and adults $(\mathrm{N}=116,787-117,794)$ and adult schizotypy $(\mathrm{N}=3,967-4,057)$. Genomic Structural Equation Modelling was performed to explore the associations while accounting for genetic influences of confounders (cannabis and alcohol use, risk-taking and insomnia). Causal associations were tested using Generalized Summary-based Mendelian Randomization (GSMR).

Results: Significant genetic correlations were found between smoking and psychiatric disorders $\left(\mathrm{r}_{\mathrm{g}}=.10-.38\right)$ and adult PE $\left(\mathrm{r}_{\mathrm{g}}=.33-.40\right)$. After accounting for covarying genetic influences, genetic associations between most smoking phenotypes and schizophrenia and depression remained but not between smoking behaviours and bipolar disorder or most psychotic experiences. GSMR results supported a causal role of smoking initiation on psychiatric disorders and adolescent cognitive and negative psychotic experiences.

Conclusions: Pleiotropy between smoking behaviours and schizophrenia and depression exists beyond the common genetic basis of known confounders. Smoking also appears to be causally associated with psychiatric disorders and with cognitive PEs and negative symptoms during adolescence. Exploration of the biological links underlying smoking and psychiatric illness would be well-justified. 
medRxiv preprint doi: https://doi.org/10.1101/2020.02.07.20021089; this version posted February 9, 2020. The copyright holder for this preprint (which was not certified by peer review) is the author/funder, who has granted medRxiv a license to display the preprint in It is made available under a CC-BY-NC-ND 4.0 International license.

\section{Introduction}

Despite declining smoking rates in high-income countries, smoking still affects a substantial proportion of the population, with $14-15 \%$ of adults in the US and UK and $28 \%$ across Europe smoking regularly (1-3). High co-occurrence between smoking behaviours and psychiatric disorders is well-established (4-6). Smoking rates among individuals diagnosed with schizophrenia or bipolar disorder are five times greater and with depression two-fold greater compared to healthy controls $(7,8)$. Smoking behaviours also co-occur with subthreshold psychiatric traits in the general population such as psychotic experiences (PE) (9-11). Regular smoking during adolescence has been associated with a range of psychotic experiences and negative symptom traits (PENS) (12).

In terms of underlying causes, a recent twin study found that regular smoking during adolescence shared genetic influences with paranoia and cognitive disorganization $\left(\mathrm{r}_{\mathrm{A}}=.37\right.$ .45), and familial influences with hallucinations (12). A previous study found no evidence that adolescent PENS was predicted by polygenic liability to initiate smoking (13), but used less well-powered genome-wide association study (GWAS) summary statistics than what are currently available. Schizophrenia and major depression share genome-wide genetic influences with smoking behaviours $(14,15)$, and polygenic liability to bipolar disorder has been associated with nicotine dependence (16).

There are several covariates that could, at a genetic level, account for potential genetic overlap between psychiatric traits or disorders and smoking behaviour. Epidemiological studies have investigated cannabis and alcohol use, stressful or traumatic life events, sociodemographic characteristics, novelty-seeking behaviour and sleep disturbances as confounders of the association between smoking behaviour and mental health problems (9$12,17-21)$. Risk-taking behaviour have also been associated with smoking $(22,23)$ and psychiatric outcomes (24). Many of these covariates, including cannabis and alcohol use, risktaking and insomnia, are partly under genetic influence and have been genetically associated 
medRxiv preprint doi: https://doi.org/10.1101/2020.02.07.20021089; this version posted February $9,2020$. The copyright holder for this preprint (which was not certified by peer review) is the author/funder, who has granted medRxiv a license to display the preprint in It is made available under a CC-BY-NC-ND 4.0 International license .

with smoking or with psychiatric traits or disorders (25-30). This issue has not been addressed in studies to date.

Smoking behaviour may be a causal risk factor for psychiatric disorders based on evidence from longitudinal and dose-response associations and Mendelian randomization studies $(17,19,21,31,32)$. Smoking behaviour may also be causally linked to PE. The association between PE and smoking is not fully explained by known confounding factors (9, 33-37, but see 33) and a dose-response relationship has been reported $(9,38)$ although not consistently $(33,36)$. Most longitudinal studies report an association between smoking behaviour and later reports of PE $(10,39-41)$ while evidence does not support the idea that adolescents start to smoke to alleviate pre-existing PE (39). However, these longitudinal associations do not necessarily reflect true causal associations because such study designs cannot completely rule out the possibility that $\mathrm{PE}$ were present prior to smoking initiation and vice-versa. Triangulation of these findings with evidence from methods such as Mendelian randomization is needed.

This study assessed the degree to which smoking behaviours are genetically correlated with PE across adolescence and adulthood and with schizophrenia, major depression and bipolar disorder. Second, we aimed to estimate the extent to which these genetic correlations remain after controlling for genetic influences on cannabis and alcohol use, risk taking behaviour and sleep disturbances (25-29). Third, we aimed to assess causal associations between smoking initiation and adult and adolescent PE and confirm previous reports of causal associations with psychiatric disorders. 
medRxiv preprint doi: https://doi.org/10.1101/2020.02.07.20021089; this version posted February $9,2020$. The copyright holder for this preprint (which was not certified by peer review) is the author/funder, who has granted medRxiv a license to display the preprint in It is made available under a CC-BY-NC-ND 4.0 International license .

\section{Methods}

\section{Samples and measures}

\section{Smoking behaviours}

Summary statistics for smoking initiation, cigarettes per day, age of initiation and current smoking $(\mathrm{N}=262,990$ - 632,802) were obtained from the GWAS and Sequencing Consortium of Alcohol and Nicotine use (GSCAN) (42) meta-GWAS on individuals of predominantly European ancestry. Smoking initiation was a binary phenotype with smokers defined as those who reported having ever smoked regularly. The average number of cigarettes per day was assessed in current and former smokers, with never-smokers excluded. Age of smoking initiation was defined as the age at which current or former smokers started smoking regularly. Current smoking was assessed among smokers and coded as either current smokers or former smokers.

\section{Adolescent psychotic experiences and negative symptoms}

Summary statistics were obtained from a mega-GWAS of four continuous scales of adolescent PENS among participants of European ancestry: Paranoia and hallucinations, cognitive disorganisation, parent-rated negative symptoms and anhedonia (N 6,297-10,098) (43). PENS items came from three community-based samples: The Twins Early Development Study (TEDS) (44) had a mean age of 16.32 years at the time of assessment, the Avon Longitudinal Study of Parents and Children (ALSPAC; mean age 16.76 years) $(45,46)$, and the Child and Adolescent Twin Study in Sweden (CATSS; mean age 18.31 years) (47).

Ethical approval for the original adolescent PENS GWAS (43) was obtained for ALSPAC from the ALSPAC Ethics and Law Committee and the Local Research Ethics Committees, for TEDS from the Institute of Psychiatry ethics committee (ref: 05/Q0706/228), and for CATSS from the Karolinska Institute Ethical Review Board. All research participants granted informed consent. 
medRxiv preprint doi: https://doi.org/10.1101/2020.02.07.20021089; this version posted February 9, 2020. The copyright holder for this preprint (which was not certified by peer review) is the author/funder, who has granted medRxiv a license to display the preprint in It is made available under a CC-BY-NC-ND 4.0 International license .

\section{Schizotypy in adulthood}

GWAS on four continuous schizotypy scales assessed during middle adulthood in the Northern Finland Birth Cohort 1996 (NFBC) (48) when participants were aged 31 years were obtained from the authors (N 3,967 - 4.057) (49). Perceptual aberrations were assessed using the Perceptual Aberration Scale (50), hypomania using the Hypomanic Personality Scale (51), social anhedonia with the Revised Social Anhedonia Scale and physical anhedonia using the Revised Physical Anhedonia Scale (52).

\section{Psychotic experiences in adults}

The presence of lifetime positive PE were assessed in the UK Biobank using four dichotomous items as part of a mental health questionnaire completed by 157,397 participants aged 40-69 years. Participants reported an average age of PE onset of 31.6 (s.d. = 17.6) years. Summary statistics for individuals of European ancestry were obtained from the Neale Lab (http://www.nealelab.is/uk-biobank) on experiences of auditory hallucinations, visual hallucinations, delusions of persecution and delusions of reference.

\section{Psychiatric disorders}

Summary statistics were obtained from the Psychiatric Genomics Consortium (https://www.med.unc.edu/pgc/results-and-downloads) meta-GWAS for schizophrenia (53) $(\mathrm{N}=150,064)$, major depressive disorder $(15)(\mathrm{N}=173,005$ excluding 23andMe participants $)$ and bipolar disorder $(54)(\mathrm{N}=41,653)$. Diagnosis of schizophrenia was based on DSM-IV criteria for schizophrenia or schizoaffective disorder. Major depression diagnoses were based on clinical interviews, obtained from electronic healthcare records or based on self-report in some UK Biobank participants. Different clinical interview formats were used to diagnose Bipolar disorder, described in full elsewhere (54).

\section{Covariates in genomic multiple regression}

Publicly available summary statistics were obtained for lifetime cannabis use $(\mathrm{N}=162,082)$ (30), alcohol consumption ( $\mathrm{N}=537,349$ excluding 23andMe participants) (42), risk taking (Neale Lab; $\mathrm{N}=348,549$ UK Biobank participants) and insomnia $(\mathrm{N}=113,006)(25)$. 
medRxiv preprint doi: https://doi.org/10.1101/2020.02.07.20021089; this version posted February $9,2020$. The copyright holder for this preprint (which was not certified by peer review) is the author/funder, who has granted medRxiv a license to display the preprint in

It is made available under a CC-BY-NC-ND 4.0 International license .

Cannabis use was a binary phenotype assessed using self-report items on whether participants had ever used cannabis. Alcohol consumption came from participant reports on the average number of weekly drinks they drank. Risk taking was assessed with the item "Would you describe yourself as someone who takes risks?” (UK Biobank data-field 2040). Insomnia was from an item from the UK Biobank (data-field 1200) with participants who indicated that they usually have trouble falling asleep at night or wake up in the middle of the night classed as cases.

The Birkbeck Department of Psychological Sciences' Ethics Committee approved this study.

\section{Analyses}

GWAS summary statistics were filtered to remove single nucleotide polymorphisms (SNPs) with incomplete association statistics and to exclude strand ambiguous and non-biallelic SNPs. Variants were matched and allele orders harmonized to the 1000 Genomes (phase 3) reference panel for European ancestry. Variants were excluded based on INFO scores $<0.9$ and minor allele frequency $(\mathrm{MAF})<0.01$. INFO scores were not provided in the summary statistics for smoking behaviours and drinks per week. Imputed variants were filtered on INFO $<0.3$ by the study authors (42). Details on summary statistics are provided in Supplementary Table 1 .

\section{LD score regression}

Genetic correlations were estimated using linkage disequilibrium (LD) score regression (55, 56). SNP heritability estimates $\left(\mathrm{SNP}-\mathrm{h}^{2}\right)$ and genetic correlations $\left(\mathrm{r}_{\mathrm{g}}\right)$ were converted to a liability scale based on a population prevalence of $1 \%$ for schizophrenia, $15 \%$ for major depression and $2 \%$ for bipolar disorder (57-59). The genetic covariance intercept was left unconstrained in analyses with overlapping samples (GWASs for smoking behaviours, depression and adult positive PE included UK Biobank participants; GWASs for smoking behaviours and adolescent PENS included ALSPAC participants). Correction for multiple 
medRxiv preprint doi: https://doi.org/10.1101/2020.02.07.20021089; this version posted February 9, 2020. The copyright holder for this preprint (which was not certified by peer review) is the author/funder, who has granted medRxiv a license to display the preprint in It is made available under a CC-BY-NC-ND 4.0 International license .

testing of genetic correlations (60 tests) was performed using Benjamini-Hochberg correction at a false discovery rate (FDR) of 0.05 .

\section{Genomic structural equation modelling}

To investigate genetic overlap between psychiatric phenotypes and smoking behaviours after accounting for the genetic influences on confounds, Genomic Structural Equation Modelling (Genomic SEM) was used (60). Genomic SEM uses summary statistics to model the shared genetic architecture of genetically correlated traits using the genetic covariance structures.

LD structure for all phenotypes in the models was estimated in LD score regression software using the same parameters described above. Genomic covariance structures were computed, and genomic multiple regression models specified in the Genomic SEM package (60) for R version 3.5.2 (61) for PE and psychiatric disorders that had at least nominally significant genetic correlations (at $p<.05$ ) with smoking phenotypes. Models allowed for covariation between the genetic components of each smoking phenotype plus the covariates as predictors regressed onto a psychiatric outcome. Standardized estimates were reported thereby allowing the association between a given predictor and the outcome to be interpreted as genetic correlations conditional on all other predictors. Model fit was evaluated based on the Standardized Root Mean Square Residual (SRMR) statistic with SRMR $<.05$ considered a good fit.

\section{Mendelian randomization}

Mendelian randomization (MR) (62) was performed to test for bi-directional causal associations between smoking initiation and psychiatric phenotypes using summary statistics.

Generalised Summary-data-based Mendelian Randomisation (GSMR; Zhu et al., 2018) was used as the main MR method due to its advantages of accounting for sampling variation in the exposure and outcome GWAS and for residual LD structure between variants used as instrumental variables (IVs). MR-Egger regression (64), Weighted Median (65) and Weighted Mode MR (66) were conducted as sensitivity analyses as these methods make different assumptions to GSMR by allowing for a proportion of invalid IVs in the analyses. 
medRxiv preprint doi: https://doi.org/10.1101/2020.02.07.20021089; this version posted February $9,2020$. The copyright holder for this preprint (which was not certified by peer review) is the author/funder, who has granted medRxiv a license to display the preprint in It is made available under a CC-BY-NC-ND 4.0 International license .

The presence of directional pleiotropy was assessed using the MR-Egger intercept test. An intercept significantly different from zero indicates that MR-Egger causal estimates may be more robust compared to GSMR estimates.

Summary statistics for major depression excluded 23andMe participants and did not have enough variants at genome-wide significance. Genome-wide significant variants to use as IVs were instead obtained from the publication (15). Only seven variants reached genomewide significance in the publicly available summary statistics for bipolar disorder (54). IVs for bipolar disorder were instead obtained from a recent GWAS for which full summary statistics were not available (67). For all other exposure phenotypes, IVs were identified using the clumping algorithm in PLINK (68) based on an $\mathrm{r}^{2}$ threshold $=.05$ within a 500kb window. Recent PE GWAS have not yet been replicated using equivalent measures in independent samples or are based on relatively small sample sizes. Thus, IVs for PE phenotypes were selected at $p<5 \times 10^{-5}$.

Analyses were performed in GSMR (Zhu et al., 2018) and MR Base (69) packages for R version 3.5.2 (R Core Team, 2018). GCTA (70) was used to calculate the LD structure between lead variants based on the 1000 Genomes (phase 3) reference panel for European ancestry. IVs excluded from GSMR analyses due to being Heidi-outliers and in residual LD at an $\mathrm{r}^{2}$ threshold of 0.1 were also removed prior to conducting MR sensitivity analyses. MR was conducted using summary statistics for smoking initiation but not for smoking phenotypes assessed in smokers only. This is because genome-wide significant associations among smokers may not explain smoking liability in samples that include non-smokers. Significance thresholds were set at $p<0.05$. 
medRxiv preprint doi: https://doi.org/10.1101/2020.02.07.20021089; this version posted February 9, 2020. The copyright holder for this preprint (which was not certified by peer review) is the author/funder, who has granted medRxiv a license to display the preprint in It is made available under a CC-BY-NC-ND 4.0 International license .

\section{Results}

\section{Genetic overlap between smoking behaviours and psychiatric traits/disorders}

Genetic correlations between smoking behaviours and psychotic experiences and psychiatric disorders are summarised in Figure 1.

Figure 1. Heat map showing genetic correlations between smoking behaviours, psychotic experiences and psychiatric disorders

\begin{tabular}{|c|c|c|c|c|c|c|c|c|c|c|c|c|c|c|c|}
\hline & \multicolumn{4}{|c|}{ Adolescent PENS } & \multicolumn{4}{|c|}{ Schizotypy in adults } & \multicolumn{4}{|c|}{ Positive PE in adults } & \multirow[b]{2}{*}{ 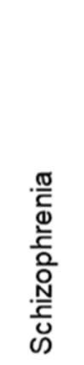 } & \multirow[b]{2}{*}{ 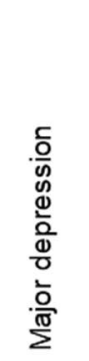 } & \multirow[b]{2}{*}{ 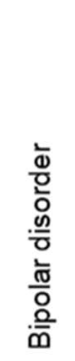 } \\
\hline & 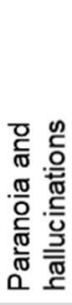 & 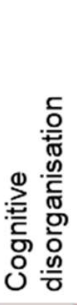 & 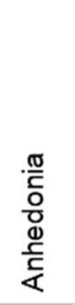 & 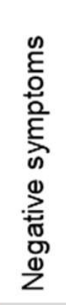 & 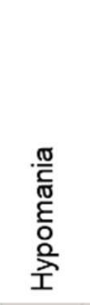 & 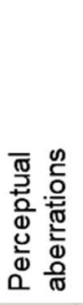 & 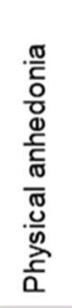 & 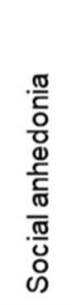 & 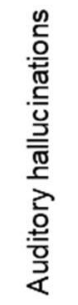 & 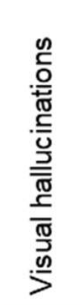 & 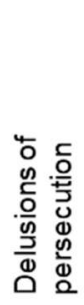 & 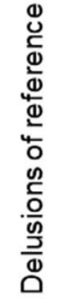 & & & \\
\hline Cigarettes per day & NA & .05 & $.40^{*}$ & NA & $.11^{\star}$ & .12 & .05 & .09 & $.28^{*}$ & $.33^{* *}$ & .22 & .02 & $.11^{\star *}$ & $.32^{\star \star}$ & $.10^{\star \star}$ \\
\hline Smoking initiation & NA & $.39^{\star}$ & -.11 & NA & $.17^{\star \star}$ & .06 & -.08 & -.02 & .14 & $.18^{*}$ & $.32^{*}$ & .07 & $.15^{\star \star}$ & $.38^{\star \star}$ & $.10^{\star \star}$ \\
\hline Age of initiation & NA & -.16 & -.02 & NA & $-.22^{\star \star}$ & .00 & -.08 & -.04 & $-.25^{\star}$ & $-.31^{\star \star}$ & -.33 & -.30 & -.02 & $-.33^{\star *}$ & .01 \\
\hline Current smoking & NA & .31 & .13 & NA & .12 & .11 & -.03 & .11 & $.40^{* *}$ & $.35^{* *}$ & .03 & .13 & $.09^{* *}$ & $.38^{* *}$ & -.02 \\
\hline
\end{tabular}

Note: PENS = Psychotic experiences $(\mathrm{PE})$ and negative symptom traits; NA = indicates that genetic correlations could not be computed due to low SNP-heritability or sample size; ${ }^{*}$ indicates statistically significant genetic correlations at $\mathrm{p}<.05$; ${ }^{*}$ indicates significance at FDR $<.05$ using Benjamini-Hochberg correction for 60 tests; Genetic correlations reported using unconstrained LD score regression intercept between phenotypes with sample overlap (for example, smoking behaviour and major depression GWASs contained participants from the UK Biobank, and smoking behaviours and adolescent PENS contained participants from ALSPAC). Note that age of smoking initiation was coded in the direction of lower scores reflecting younger ages of initiation. Note that current smoking cases are current smokers (compared to ex-smokers).

For positive PE in adults, significant genetic correlations after correction for multiple testing were observed between experiences of visual hallucinations with cigarettes per day $\left(\mathrm{r}_{\mathrm{g}}\right.$ $\left.=.33, p=4.00 \times 10^{-4}\right)$, age of smoking initiation $\left(\mathrm{r}_{\mathrm{g}}=-.31, p=0.002\right)$, current smoking $\left(\mathrm{r}_{\mathrm{g}}=\right.$ $.35, p=0.001)$, and nominally at $p<.05$ with smoking initiation $\left(\mathrm{r}_{\mathrm{g}}=.18, p=0.026\right)$. 
medRxiv preprint doi: https://doi.org/10.1101/2020.02.07.20021089; this version posted February 9, 2020. The copyright holder for this preprint (which was not certified by peer review) is the author/funder, who has granted medRxiv a license to display the preprint in It is made available under a CC-BY-NC-ND 4.0 International license .

Experiences of auditory hallucinations was significantly genetically correlated with current smoking $\left(\mathrm{r}_{\mathrm{g}}=.40, p=0.009\right)$, and nominally significant with cigarettes per day $\left(\mathrm{r}_{\mathrm{g}}=.28, p=\right.$ $0.015)$ and age of smoking initiation $\left(\mathrm{r}_{\mathrm{g}}=-.25, \mathrm{p}=0.037\right)$. Delusions of persecution was genetically correlated at nominal significance with smoking initiation $\left(\mathrm{r}_{\mathrm{g}}=.32, p=0.016\right)$.

Hypomania was the only schizotypy measure to genetically correlate with smoking behaviours, specifically with smoking initiation $\left(\mathrm{r}_{\mathrm{g}}=.17, p=8.00 \times 10^{-4}\right)$, age of smoking initiation $\left(r_{\mathrm{g}}=-.22, p=0.002\right)$ and at nominal significance with cigarettes per day $\left(\mathrm{r}_{\mathrm{g}}=.11, p=\right.$ $0.049)$.

For adolescent PENS, nominally significant genetic correlations were found between cognitive disorganisation and smoking initiation $\left(\mathrm{r}_{\mathrm{g}}=.39, p=0.017\right)$ and between anhedonia and cigarettes per day $\left(\mathrm{r}_{\mathrm{g}}=.40, p=0.046\right)$. We could not estimate genetic correlations for paranoia and hallucinations and negative symptoms due to the low SNP-h ${ }^{2}$. To indicate presence and direction of genetic overlap, we instead report genetic covariances. After correction for multiple testing, significant genetic covariation in the expected directions were found between paranoia and hallucinations with smoking initiation $\left(\rho_{\mathrm{g}}=0.02, p=0.010\right)$ and age of smoking initiation $\left(\rho_{\mathrm{g}}=-0.03, p=1.16 \times 10^{-4}\right)$, and between negative symptoms and smoking initiation $\left(\rho_{\mathrm{g}}=0.03, p=0.001\right)$. Genetic covariation was also suggested (at $\left.p<.05\right)$ between negative symptoms with cigarettes per day $\left(\rho_{\mathrm{g}}=0.02, p=0.046\right)$ and with current smoking $\left(\rho_{g}=0.02, p<0.050\right)$.

As expected, we found significant genetic correlations between smoking behaviours and psychiatric disorders (42). Schizophrenia was genetically correlated with cigarettes per day $\left(\mathrm{r}_{\mathrm{g}}=.11, p=2.00 \times 10^{-4}\right)$, smoking initiation $\left(\mathrm{r}_{\mathrm{g}}=.15, p=9.51 \times 10^{-11}\right)$ and current smoking $\left(r_{g}=.09, p=0.008\right)$. Major depression shared genetic influences with cigarettes per day $\left(\mathrm{r}_{\mathrm{g}}=.32, p=6.15 \times 10^{-12}\right)$, smoking initiation $\left(\mathrm{r}_{\mathrm{g}}=.38, p=1.57 \times 10^{-29}\right)$, age of smoking initiation $\left(\mathrm{r}_{\mathrm{g}}=-.33, p=1.16 \times 10^{-14}\right)$ and current smoking $\left(\mathrm{r}_{\mathrm{g}}=.38, p=1.31 \times 10^{-14}\right)$. Significant genetic correlations were found between bipolar disorder and cigarettes per day $\left(\mathrm{r}_{\mathrm{g}}=.10, p=\right.$ $0.006)$ and smoking initiation $\left(\mathrm{r}_{\mathrm{g}}=.10, p=7.00 \times 10^{-4}\right)$. 
medRxiv preprint doi: https://doi.org/10.1101/2020.02.07.20021089; this version posted February 9, 2020. The copyright holder for this preprint (which was not certified by peer review) is the author/funder, who has granted medRxiv a license to display the preprint in It is made available under a CC-BY-NC-ND 4.0 International license .

\section{Genomic multiple regression}

To investigate the degree to which genetic correlations between smoking behaviours and psychiatric traits and disorders exist beyond genetic influences associated with covariates (lifetime cannabis use, alcohol consumption, insomnia and risk-taking behaviour), genomic multiple regression models were run in Genomic SEM for phenotype pairs that shared at least nominally significant $(p<.05)$ genetic overlap (presented above and in Figure 1). Genetic correlations with the covariates are shown in Supplementary Figure 1.

Figure 2. Path diagram illustrating genetic multiple regression models

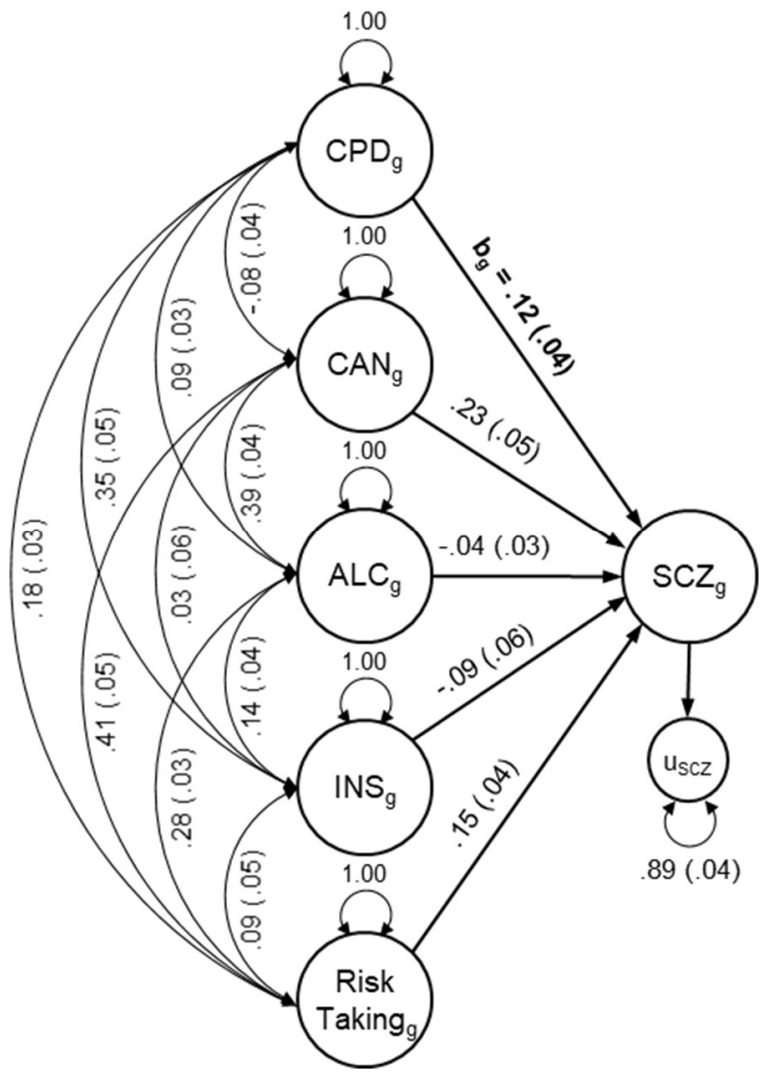

Note: $\mathrm{CPDg}$ = Genetic component of cigarettes per day; $\mathrm{CANg}$ = Genetic component of cannabis use; ALCg = Genetic component of alcohol consumption; INSg = Genetic component of insomnia; SCZg = Genetic component of schizophrenia; $\mathrm{u}$ = residual genetic variance; $\mathrm{bg}=$ Conditional genetic correlation between the genetic components of cigarettes per day and schizophrenia as summarized in Table 1; Doubleheaded arrows represents genetic covariance; Single-headed arrows represents regression paths; Path diagrams for models between all smoking behaviours and psychiatric phenotypes are provided in Supplementary Figures 2-5. 
medRxiv preprint doi: https://doi.org/10.1101/2020.02.07.20021089; this version posted February $9,2020$. The copyright holder for this preprint (which was not certified by peer review) is the author/funder, who has granted medRxiv a license to display the preprint in It is made available under a CC-BY-NC-ND 4.0 International license .

Table 1. Conditional genetic correlations after accounting for genetic influences on covariates in genomic structural equation models

\begin{tabular}{llcccc}
\hline & & \multicolumn{2}{c}{$\begin{array}{c}\text { LD score } \\
\text { regression }\end{array}$} & \multicolumn{3}{c}{$\begin{array}{c}\text { Standardized conditional } \\
\text { genetic associations }\end{array}$} \\
\cline { 3 - 6 } Psychotic disorders & Smoking behaviours & $\mathbf{r}_{\mathbf{g}}$ & $\mathbf{b}_{\mathbf{g}}$ & SE & $\boldsymbol{p}$ \\
\hline Schizophrenia & Cigarettes per day & 0.11 & 0.12 & 0.04 & 0.003 \\
Schizophrenia & Smoking initiation & 0.15 & 0.00 & 0.04 & 0.970 \\
Schizophrenia & Current smoking & 0.09 & 0.12 & 0.05 & 0.009 \\
Major depression & Cigarettes per day & 0.32 & 0.17 & 0.06 & 0.003 \\
Major depression & Smoking initiation & 0.38 & 0.16 & 0.07 & 0.017 \\
Major depression & Age of smoking initiation & -0.33 & -0.11 & 0.06 & 0.075 \\
Major depression & Current smoking & 0.39 & 0.30 & 0.07 & $1.93 \times 10^{-5}$ \\
Bipolar disorder & Cigarettes per day & 0.10 & 0.05 & 0.05 & 0.263 \\
Bipolar disorder & Smoking initiation & 0.10 & -0.11 & 0.05 & 0.029
\end{tabular}

\section{Adult PE}

$\begin{array}{llllll}\text { Auditory hallucinations } & \text { Cigarettes per day } & 0.28 & 0.05 & 0.12 & 0.662 \\ \text { Auditory hallucinations } & \text { Age of smoking initiation } & -0.25 & 0.00 & 0.12 & 0.999 \\ \text { Auditory hallucinations } & \text { Current smoking } & 0.40 & 0.21 & 0.14 & 0.125 \\ \text { Visual hallucinations } & \text { Cigarettes per day } & 0.33 & 0.18 & 0.13 & 0.165 \\ \text { Visual hallucinations } & \text { Smoking initiation } & 0.18 & 0.14 & 0.12 & 0.266 \\ \text { Visual hallucinations } & \text { Age of smoking initiation } & -0.31 & -0.15 & 0.13 & 0.248 \\ \text { Visual hallucinations } & \text { Current smoking } & 0.35 & 0.26 & 0.13 & 0.044 \\ \text { Delusions of persecution } & \text { Smoking initiation } & 0.32 & 0.20 & 0.18 & 0.258\end{array}$

\section{Schizotypy}

Hypomania

Hypomania

Hypomania
Cigarettes per day

Smoking initiation

Age of smoking initiation

\subsection{1}

0.17

$-0.22$
$-0.01$

0.17

0.00

0.16

$-0.04$

0.16

0.980

0.820

\section{Adolescent PENS}

Anhedonia

Cigarettes per day

0.40

0.44

0.22

0.044

Cognitive disorganization

Smoking initiation

0.39

$0.09 \quad 0.22$

0.676

Note: $\mathrm{r}_{\mathrm{g}}=$ Bivariate genetic correlation estimates caluclated in LD score regression; $\mathrm{b}_{\mathrm{g}}=$ Conditional genetic association estimates obtained from Genomic Structural Equasion Modelling that, in standardized form, can be interpreted as conditional genetic correlations accounting for genetic covariation between predictors and regression paths of covariates onto psychiatric outcomes; PE = Psychotic experiences; PENS $=$ Psychotic experiences and negative symtom traits. 
medRxiv preprint doi: https://doi.org/10.1101/2020.02.07.20021089; this version posted February 9, 2020. The copyright holder for this preprint (which was not certified by peer review) is the author/funder, who has granted medRxiv a license to display the preprint in It is made available under a CC-BY-NC-ND 4.0 International license .

All models provided excellent fit to the data (maximum SRMR $\left.=8.30 \times 10^{-9}\right)$. Figure 2 shows the path diagram between schizophrenia and cigarettes per day as an example of the genomic multiple regression models (see Supplementary Figures 2-5 for path diagrams for all models). Table 1 summarizes the conditional genetic correlations $\left(b_{\mathrm{g}}\right)$ between smoking behaviours and psychiatric disorders/PE obtained from these models.

The genetic component of cigarettes per day, plus the genetic influences on the four covariates as predictors, accounted for $11-41 \%$ of genetic variation in psychiatric traits and disorders (calculated as one minus the residual variance). Models using the genetic component of smoking initiation accounted for $10-52 \%$, using age of smoking initiation 24 $41 \%$, and using current smoking status $11-41 \%$ of genetic variation in psychiatric traits and disorders.

Table 1 shows that after accounting for the genetic influences of the other covariates, conditional genetic associations $\left(b_{\mathrm{g}}\right)$ were significant between cigarettes per day and schizophrenia (unattenuated compared to $r_{g}$ estimates from LD score regression), depression (with $b_{g}$ accounting for $53 \%$ of $r_{g}$; calculated $a_{s} b_{g} / r_{g} \times 100$ ) and adolescent anhedonia (unattenuated) but not with bipolar disorder, auditory hallucinations, visual hallucinations and hypomania.

Significant conditional genetic associations were found between smoking initiation and depression (accounting for $42 \%$ of the $\mathrm{r}_{\mathrm{g}}$ estimate from LD score regression) and a negative conditional genetic association with bipolar disorder (whereas $r_{g}$ from LD score regression was positive). No genetic association was found between smoking initiation and schizophrenia, visual hallucinations, delusions of persecution, hypomania and adolescent cognitive disorganization after accounting for the genetic influences of covariates.

No significant conditional genetic associations were found between age of smoking initiation with depression, auditory hallucinations, visual hallucinations and hypomania. Negative conditional genetic association estimates indicate an association with a younger age of smoking initiation. 
medRxiv preprint doi: https://doi.org/10.1101/2020.02.07.20021089; this version posted February $9,2020$. The copyright holder for this preprint (which was not certified by peer review) is the author/funder, who has granted medRxiv a license to display the preprint in

It is made available under a CC-BY-NC-ND 4.0 International license .

Significant genetic overlap not accounted for by other predictors in the model was found between current smoking and schizophrenia (with $b_{g}$ being slightly higher than the $r_{g}$ estimate from LD score regression), depression (accounting for $79 \%$ of $\mathrm{r}_{\mathrm{g}}$ from LD score regression) and visual hallucinations ( $74 \%$ of $r_{g}$ from $L D$ score regression) and not with auditory hallucinations.

\section{Mendelian randomization}

Table 2 presents MR results (see also Supplementary Figures 6-13 and Supplementary Table 2). GSMR analyses suggested a causal association between smoking initiation on schizophrenia liability with this finding replicated in Weighted Median but not in MR-Egger or Weighted Mode sensitivity analyses. A significant but smaller causal effect of schizophrenia liability on smoking propensity was found.

Evidence of a causal association between smoking initiation and liability to major depression was found and a similar effect size was observed in MR-Egger (but with larger standard error), and replicated in Weighted Median and Weighted Mode MR. MR-Egger indicated that depression liability had a small but significant causal effect on smoking initiation. While this effect was not found in the other MR methods, the MR-Egger intercept was significantly different from zero $\left(p=5.53 \times 10^{-5}\right)$ suggesting the presence of directional pleiotropy, in which case the MR-Egger estimate is likely to be less biased than those of the other methods.

Evidence of a causal association between smoking initiation on liability for bipolar disorder was reported in GSMR and Weighted Median analyses with a similar effect size observed in MR-Egger, but not replicated in the Weighted Mode analysis. No evidence of reverse causation was found.

Some evidence of a causal effect of smoking initiation was observed for cognitive disorganisation in GSMR and Weighted Median analyses but was not replicated in MR-Egger 
medRxiv preprint doi: https://doi.org/10.1101/2020.02.07.20021089; this version posted February 9, 2020. The copyright holder for this preprint (which was not certified by peer review) is the author/funder, who has granted medRxiv a license to display the preprint in It is made available under a CC-BY-NC-ND 4.0 International license.

and Weighted Mode MR, and on negative symptoms in the main MR analyses but not replicated in MR sensitivity analyses. No evidence of reverse causation was observed. 
Table 2. Mendelian Randomization results.

\begin{tabular}{|c|c|c|c|c|c|c|c|c|c|c|c|c|c|c|c|c|c|}
\hline \multirow{2}{*}{ Exposure } & \multirow{2}{*}{\multicolumn{2}{|c|}{ Outcome }} & \multirow{2}{*}{$\begin{array}{l}\text { Heidi } \\
\text { SNPs }\end{array}$} & \multirow{2}{*}{$\begin{array}{l}\text { LD } \\
\text { SNPs }\end{array}$} & \multirow{2}{*}{$\begin{array}{c}n \\
\text { SNP }\end{array}$} & \multicolumn{3}{|c|}{ GSMR results } & \multicolumn{3}{|c|}{ MR-Egger } & \multicolumn{3}{|c|}{ Weighted Median } & \multicolumn{3}{|c|}{ Weighted Mode } \\
\hline & & & & & & Beta & $\mathrm{SE}$ & $p$ & Beta & SE & $p$ & Beta & $\mathrm{SE}$ & $P$ & Beta & SE & $p$ \\
\hline Smoking initiation & $\rightarrow$ & Schizophrenia & 9 & 3 & 102 & 0.653 & 0.113 & $6.89 \times 10^{-9}$ & 0.022 & 0.900 & 0.981 & 0.496 & 0.192 & 0.010 & -0.372 & 0.812 & 0.647 \\
\hline Schizophrenia & $\rightarrow$ & Smoking initiation & 12 & 11 & 81 & 0.011 & 0.003 & $4.12 \times 10^{-4}$ & 0.016 & 0.019 & 0.398 & 0.010 & 0.005 & 0.031 & -0.006 & 0.012 & 0.630 \\
\hline Smoking initiation & $\rightarrow$ & Major depression & 6 & 2 & 103 & 0.854 & 0.083 & $1.51 \times 10^{-24}$ & 0.834 & 0.516 & 0.109 & 0.809 & 0.129 & $3.84 \times 10^{-10}$ & 0.852 & 0.297 & 0.005 \\
\hline Major depression & $\rightarrow$ & Smoking initiation & 4 & 0 & 28 & 0.000 & 0.000 & 0.638 & 0.073 & 0.015 & $5.34 \times 10^{-5}$ & 0.000 & 0.001 & 0.611 & -0.001 & 0.002 & 0.761 \\
\hline Smoking initiation & $\rightarrow$ & Bipolar disorder & 4 & 3 & 106 & 0.812 & 0.151 & $7.82 \times 10^{-8}$ & 0.795 & 0.955 & 0.407 & 0.800 & 0.232 & 0.001 & 0.893 & 0.542 & 0.102 \\
\hline Bipolar disorder & $\rightarrow$ & Smoking initiation & 0 & 0 & 18 & 0.006 & 0.007 & 0.356 & -0.098 & 0.058 & 0.112 & -0.003 & 0.010 & 0.755 & -0.009 & 0.016 & 0.562 \\
\hline Smoking initiation & $\rightarrow$ & Auditory hallucinations & 0 & 3 & 116 & 0.003 & 0.005 & 0.496 & 0.013 & 0.023 & 0.573 & 0.002 & 0.007 & 0.761 & 0.013 & 0.020 & 0.527 \\
\hline Auditory hallucinations & $\rightarrow$ & Smoking initiation & 0 & 0 & 89 & 0.041 & 0.085 & 0.631 & 0.297 & 0.186 & 0.113 & 0.119 & 0.117 & 0.310 & 0.197 & 0.334 & 0.557 \\
\hline Smoking initiation & $\rightarrow$ & Visual hallucinations & 1 & 3 & 115 & 0.010 & 0.007 & 0.169 & 0.030 & 0.033 & 0.358 & 0.014 & 0.010 & 0.172 & -0.007 & 0.024 & 0.781 \\
\hline Visual hallucinations & $\rightarrow$ & Smoking initiation & 0 & 0 & 81 & 0.043 & 0.066 & 0.513 & 0.128 & 0.154 & 0.408 & -0.005 & 0.089 & 0.958 & -0.205 & 0.225 & 0.365 \\
\hline Smoking initiation & $\rightarrow$ & Delusions of reference & 0 & 3 & 116 & 0.003 & 0.003 & 0.325 & 0.026 & 0.015 & 0.077 & 0.004 & 0.005 & 0.454 & 0.008 & 0.013 & 0.568 \\
\hline Delusions of reference & $\rightarrow$ & Smoking initiation & 0 & 0 & 105 & 0.005 & 0.125 & 0.970 & -0.036 & 0.259 & 0.890 & -0.062 & 0.173 & 0.722 & -0.296 & 0.458 & 0.520 \\
\hline Smoking initiation & $\rightarrow$ & Delusions of persecution & 0 & 3 & 116 & 0.005 & 0.003 & 0.171 & 0.008 & 0.015 & 0.624 & 0.002 & 0.005 & 0.688 & 0.000 & 0.012 & 0.995 \\
\hline Delusions of persecution & $\rightarrow$ & Smoking initiation & 0 & 0 & 92 & 0.035 & 0.126 & 0.778 & 0.137 & 0.309 & 0.657 & 0.027 & 0.182 & 0.882 & 0.212 & 0.462 & 0.647 \\
\hline Smoking initiation & $\rightarrow$ & Hypomania & 0 & 3 & 98 & 0.235 & 0.234 & 0.316 & 0.069 & 1.120 & 0.951 & 0.111 & 0.358 & 0.757 & -0.040 & 0.841 & 0.962 \\
\hline Hypomania & $\rightarrow$ & Smoking initiation & 0 & 0 & 68 & -0.001 & 0.002 & 0.565 & -0.004 & 0.005 & 0.494 & -0.002 & 0.003 & 0.461 & -0.003 & 0.006 & 0.577 \\
\hline Smoking initiation & $\rightarrow$ & Perceptual aberrations & 0 & 3 & 98 & 0.036 & 0.232 & 0.878 & 0.591 & 1.168 & 0.614 & 0.154 & 0.339 & 0.649 & 0.591 & 1.168 & 0.614 \\
\hline Perceptual aberrations & $\rightarrow$ & Smoking initiation & 0 & 0 & 54 & 0.000 & 0.002 & 0.867 & -0.001 & 0.005 & 0.792 & -0.001 & 0.003 & 0.732 & 0.000 & 0.006 & 0.953 \\
\hline Smoking initiation & $\rightarrow$ & Physical anhedonia & 0 & 3 & 98 & -0.139 & 0.234 & 0.553 & -0.464 & 1.201 & 0.700 & -0.170 & 0.360 & 0.636 & -0.180 & 0.788 & 0.820 \\
\hline Physical anhedonia & $\rightarrow$ & Smoking initiation & 1 & 0 & 58 & 0.000 & 0.002 & 0.850 & 0.003 & 0.006 & 0.626 & 0.002 & 0.003 & 0.524 & 0.010 & 0.008 & 0.209 \\
\hline Smoking initiation & $\rightarrow$ & Social anhedonia & 0 & 3 & 98 & -0.414 & 0.233 & 0.076 & -0.579 & 1.118 & 0.605 & -0.469 & 0.347 & 0.177 & -0.326 & 0.861 & 0.706 \\
\hline Social anhedonia & $\rightarrow$ & Smoking initiation & 1 & 0 & 57 & -0.001 & 0.002 & 0.754 & 0.005 & 0.005 & 0.294 & 0.002 & 0.003 & 0.578 & 0.004 & 0.006 & 0.530 \\
\hline Smoking initiation & $\rightarrow$ & Paranoia/hallucinations & 0 & 1 & 57 & 0.282 & 0.213 & 0.185 & 0.437 & 0.997 & 0.663 & 0.073 & 0.296 & 0.804 & -0.056 & 0.564 & 0.922 \\
\hline Paranoia/hallucinations & $\rightarrow$ & Smoking initiation & 0 & 0 & 24 & -0.002 & 0.006 & 0.720 & -0.015 & 0.015 & 0.330 & -0.006 & 0.008 & 0.460 & -0.015 & 0.014 & 0.322 \\
\hline Smoking initiation & $\rightarrow$ & Cognitive disorganisation & 0 & 1 & 57 & 1.030 & 0.261 & $8.02 \times 10^{-5}$ & 2.321 & 1.191 & 0.056 & 1.267 & 0.365 & $5.25 \times 10^{-4}$ & 1.352 & 0.691 & 0.055 \\
\hline Cognitive disorganisation & $\rightarrow$ & Smoking initiation & 0 & 0 & 28 & 0.004 & 0.004 & 0.307 & -0.022 & 0.011 & 0.059 & 0.002 & 0.006 & 0.723 & -0.001 & 0.010 & 0.943 \\
\hline Smoking initiation & $\rightarrow$ & Anhedonia & 0 & 1 & 57 & 0.058 & 0.244 & 0.812 & -0.841 & 1.208 & 0.490 & -0.075 & 0.362 & 0.835 & -0.218 & 0.604 & 0.720 \\
\hline Anhedonia & $\rightarrow$ & Smoking initiation & 0 & 0 & 30 & -0.002 & 0.004 & 0.599 & 0.000 & 0.009 & 0.965 & 0.000 & 0.006 & 0.944 & 0.002 & 0.011 & 0.868 \\
\hline Smoking initiation & & Negative symptoms & 0 & 1 & 57 & 0.506 & 0.204 & 0.013 & 1.221 & 1.089 & 0.267 & 0.450 & 0.302 & 0.136 & 0.529 & 0.533 & 0.326 \\
\hline Negative symptoms & $\rightarrow$ & Smoking initiation & 0 & 0 & 25 & -0.003 & 0.006 & 0.609 & -0.012 & 0.015 & 0.436 & -0.004 & 0.008 & 0.664 & 0.004 & 0.015 & 0.780 \\
\hline
\end{tabular}

Note: GSMR = Generalized Summary-based Mendelian Randomization; LD SNPs = SNPs with residual LD at $\mathrm{r}^{2}>0.1$ removed from analysis; $\mathrm{n}$ SNPs $=$ number of variants remaining in analyses after those identified as Heidi-outliers or with residual LD were removed. SNPs identified as having residual LD and as Heidi outliers were also excluded from MR Egger, Weighted Median and Weighted Mode analyses. Bold text indicates significant $\mathrm{p}$-values at $\mathrm{p}<0.05$. 
medRxiv preprint doi: https://doi.org/10.1101/2020.02.07.20021089; this version posted February 9, 2020. The copyright holder for this preprint (which was not certified by peer review) is the author/funder, who has granted medRxiv a license to display the preprint in It is made available under a CC-BY-NC-ND 4.0 International license .

\section{Discussion}

Smoking is the leading cause of preventable deaths and smoking rates are modifiable: they can be reduced through population-based interventions. We found evidence of overlapping genome-wide genetic influences between smoking behaviours and psychiatric disorders as well as between smoking behaviours and specific types of PE and negative symptom traits reported by adolescents and adults in the community. We further investigated the nature of pleiotropy between smoking behaviours and psychiatric traits and disorders. For schizophrenia and depression, overlap in common genetic influences associated with smoking frequency and current smoking status was not fully explained by genetic influences on known covariates, namely cannabis use, alcohol use, risk taking and insomnia. Genetic associations between smoking behaviours and most positive PE were explained by genetic influences shared with the covariates. We found evidence of causal effects of smoking initiation on schizophrenia, depression and bipolar disorder, as well as on adolescent cognitive and (to some degree) negative symptoms.

Our findings support the hypothesis that schizophrenia and depression share genetic pathways with smoking frequency and persistent smoking. Possible shared biological pathways may involve nicotine, the principal pharmacologically active component of smoking that acts as an agonist on the nicotinic acetylcholine receptor (nAChR). Variants within the CHRNA5-A3-B4 gene cluster which encodes for subunits of nAChR are among the most robust associations with nicotine dependence $(42,71-73)$ and have also been implicated in schizophrenia (53). Presynaptic activation of nAChR stimulates the release of several neurotransmitters including dopamine, serotonin and glutamate (74-77). Dysregulation of dopaminergic and glutamatergic pathways could both explain why some people may be more susceptible to the positive reinforcing effects of smoking (78) and have an increased vulnerability to develop schizophrenia (79).

We found support for a causal role of smoking initiation on liabilities to develop schizophrenia, depression and bipolar disorder, similar to the findings from two recent studies $(31,32)$ whilst using different Mendelian randomization methods. Our study took 
medRxiv preprint doi: https://doi.org/10.1101/2020.02.07.20021089; this version posted February 9, 2020. The copyright holder for this preprint (which was not certified by peer review) is the author/funder, who has granted medRxiv a license to display the preprint in It is made available under a CC-BY-NC-ND 4.0 International license .

steps to remove likely pleiotropic variants from genetic instruments which aims to reduce confounding from biological pleiotropy. Our results of a possible causal effect of smoking on schizophrenia and depression (and a possible weaker effect in the other direction) concurs with meta-analytic findings of longitudinal studies $(19,21)$.

The action of nicotine on $\mathrm{nAChR}$ could also explain possible mechanisms by which smoking could be causally associated with psychiatric disorders. Chronic exposure to nicotine may result in long-lasting alterations of dopaminergic and cholinergic pathways, leading to an increase in risk of psychiatric disorders (80-82). Beyond nicotine, other toxic compounds released during combustion of tobacco cause neuro-inflammation and oxidative stress (Goncalves et al., 2011), factors that are associated with psychiatric disorders (Berk et al., 2011; Howes \& McCutcheon, 2017; Miller, Maletic, \& Raison, 2009).

To our knowledge, this is the first study to report that genome-wide genetic influences on bipolar disorder significantly overlap with those on smoking frequency and initiation. This finding supports recent evidence of an association between polygenic scores for bipolar disorder and nicotine dependence (16). Genetic overlap between bipolar disorder and smoking quantity was accounted for by genetic influences on the covariates. Interestingly, we found that smoking initiation was associated with lower genetic liability to be diagnosed with bipolar disorder, while the bivariate genetic correlation between these two phenotypes was positive. The negative conditional genetic association was likely due to smoking initiation being genetically correlated with all covariates $\left(\mathrm{r}_{\mathrm{g}}=.25-.51\right)$.

Until recently, research into the genetic etiology underlying the association between $\mathrm{PE}$ in the community and smoking behaviours was lacking. Here, we found novel evidence that smoking behaviours share genetic influences with some types of positive PE during adulthood (notably with visual and auditory hallucinations) and with hypomania. Interestingly, for most associations, the genetic overlap between PE and smoking was shared with the covariates. We found suggestive evidence $(\mathrm{p}<.05)$ that adolescent anhedonia was genetically associated with cigarettes per day even after accounting for the genetic influences on confounds. 
medRxiv preprint doi: https://doi.org/10.1101/2020.02.07.20021089; this version posted February 9, 2020. The copyright holder for this preprint (which was not certified by peer review) is the author/funder, who has granted medRxiv a license to display the preprint in It is made available under a CC-BY-NC-ND 4.0 International license.

Smoking may increase a propensity to experience cognitive and negative PE during adolescence, although the association with negative symptom traits were not confirmed by Mendelian randomization sensitivity analyses. A recent preclinical study found that during adolescence, exposure to nicotine could lead to persistent alteration of neurotransmitter pathways (81) likely relevant to PE. Another possible causal mechanism is the effect of nitrogen oxides: Nitrogen oxide levels in air pollution was recently linked to an increased risk of PE in adolescents (83) and it is a toxin produced during cigarette smoking.

We replicated previous findings of genetic overlap between smoking behaviours and schizophrenia and major depression using more recent and better powered GWAS results $(14,15)$. We found a slightly higher genetic correlation of .38 between major depression and smoking initiation than the value of .29 reported by Wray et al. (15) and genetic correlations of similar magnitude with the other smoking phenotypes.

Smoking initiation and positive PE in adulthood did not appear to be causally related. This is somewhat surprising given the known phenotypic association between PE and psychiatric disorders (84-89) and could be explored further. Evidence suggests PE in adults have somewhat different underlying causal influences to PE during adolescence (90) and this may explain that lack of causal associations of PE in later life with smoking behaviours.

This study had limitations that should be considered. Our findings on schizotypy and adolescent PENS were limited by the relatively small GWAS sample sizes. As such, in some genomic multiple regression models the standard errors of the residual variances were large. We were unable to include some additional potential confounds such as exposure to trauma and sociodemographic characteristics. Large biobanks include biases from ascertainment and attrition. However, we note that attrition based on phenotypic or genetic risk for mental health conditions would lead us, if anything, to underestimate the genetic overlap between psychiatric disorders and traits with smoking behaviours in our analyses. 
medRxiv preprint doi: https://doi.org/10.1101/2020.02.07.20021089; this version posted February $9,2020$. The copyright holder for this preprint (which was not certified by peer review) is the author/funder, who has granted medRxiv a license to display the preprint in

It is made available under a CC-BY-NC-ND 4.0 International license .

\section{Acknowledgements}

This work was supported by the UK Medical Research Council (G1100559 to AR) and a Wellcome Trust ISSF grant (204770/Z/16/Z) and the Camara-Rijvers David Studentship to WB.

The authors gratefully acknowledge the ongoing contribution of the participants and their families in the Twins Early Development Study (TEDS), the Avon Longitudinal Study of Children and Parents (ALSPAC), the Child and Adolescent Twin Study in Sweden (CATSS) and participants in the North Finland Birth Cohort (NFBC) and the UK Biobank. We thank the funding bodies and research teams which includes interviewers, computer and laboratory technicians, clerical workers, research scientists, volunteers, managers, receptionists and nurses. The data from TEDS was supported by a program grant to Robert Plomin from the UK Medical Research Council (MR/M021475/1) and UK Medical Research Council grant G1100559 to AR. The UK Medical Research Council and Wellcome (Grant ref: 102215/2/13/2) and the University of Bristol provide core support for ALSPAC. This publication is the work of the authors and WB and AR will serve as guarantors for its contents. ALSPAC GWAS data was generated by Sample Logistics and Genotyping Facilities at Wellcome Sanger Institute and LabCorp (Laboratory Corporation of America) using support from 23andMe. We thank the Neale Lab and the Psychiatric Genomics Consortium (PGC) for providing genetic summary results and Dr. W. Hennah and A. Ortega-Alonso for preparing and sharing the schizotypy summary statistics. The authors are very grateful to Andrew Grotzinger for his advice on the implementation and interpretation of genomic multiple regression models performed within the Genomic Structural Equation Modelling software. 
medRxiv preprint doi: https://doi.org/10.1101/2020.02.07.20021089; this version posted February 9, 2020. The copyright holder for this preprint (which was not certified by peer review) is the author/funder, who has granted medRxiv a license to display the preprint in It is made available under a CC-BY-NC-ND 4.0 International license .

\section{References}

1. Office for National Statistics (2019): Adult smoking habits in the UK: 2018. London: Office for National Statistics. Retrieved August 14, 2019, from https://www.ons.gov.uk/peoplepopulationandcommunity/healthandsocialcare/healthandlifee xpectancies/bulletins/adultsmokinghabitsingreatbritain/2018.

2. Centers for Disease Control and Prevention (2019): Current Cigarette Smoking Among Adults in the United States. Retrieved August 14, 2019, from https://www.cdc.gov/tobacco/data_statistics/fact_sheets/adult_data/cig_smoking/index.htm. 3. World Health Organization (2019): European Tobacco Use: Trends Report 2019. Retrieved September 6, 2019, from http://www.euro.who.int/_data/assets/pdf_file/0009/402777/Tobacco-Trends-Report-ENGWEB.pdf?ua=1.

4. de Leon J, Diaz FJ (2005): A meta-analysis of worldwide studies demonstrates an association between schizophrenia and tobacco smoking behaviors. Schizophr Res. 76:135157.

5. Lawrence D, Mitrou F, Zubrick SR (2009): Smoking and mental illness: results from population surveys in Australia and the United States. BMC Public Health. 9:285.

6. Thomson D, Berk M, Dodd S, Rapado-Castro M, Quirk SE, Ellegaard PK, et al. (2015): Tobacco use in bipolar disorder. Clin Psychopharmacol Neurosci. 13:1-11.

7. Prochaska JJ, Das S, Young-Wolff KC (2017): Smoking, Mental Illness, and Public Health. Annu Rev Public Health. 38:165-185.

8. Hartz SM, Pato CN, Medeiros H, Cavazos-Rehg P, Sobell JL, Knowles JA, et al. (2014): Comorbidity of severe psychotic disorders with measures of substance use. JAMA Psychiatry. $71: 248-254$.

9. Bhavsar V, Jauhar S, Murray RM, Hotopf M, Hatch SL, McNeill A, et al. (2018):

Tobacco smoking is associated with psychotic experiences in the general population of South London. Psychol Med. 48:123-131. 
medRxiv preprint doi: https://doi.org/10.1101/2020.02.07.20021089; this version posted February 9, 2020. The copyright holder for this preprint (which was not certified by peer review) is the author/funder, who has granted medRxiv a license to display the preprint in It is made available under a CC-BY-NC-ND 4.0 International license .

10. Gage SH, Hickman M, Heron J, Munafo MR, Lewis G, Macleod J, et al. (2014):

Associations of cannabis and cigarette use with psychotic experiences at age 18: findings from the Avon Longitudinal Study of Parents and Children. Psychol Med. 44:3435-3444.

11. Jones HJ, Gage SH, Heron J, Hickman M, Lewis G, Munafo MR, et al. (2018): Association of Combined Patterns of Tobacco and Cannabis Use in Adolescence With Psychotic Experiences. JAMA Psychiatry. 75:240-246.

12. Barkhuizen W, Taylor MJ, Freeman D, Ronald A (2019): A Twin Study on the Association Between Psychotic Experiences and Tobacco Use During Adolescence. J Am Acad Child Adolesc Psychiatry. 58:267-276.e268.

13. Krapohl E, Euesden J, Zabaneh D, Pingault JB, Rimfeld K, von Stumm S, et al. (2016): Phenome-wide analysis of genome-wide polygenic scores. Mol Psychiatry. 21:1188-1193.

14. Hartz SM, Horton AC, Hancock DB, Baker TB, Caporaso NE, Chen LS, et al. (2017):

Genetic correlation between smoking behaviors and schizophrenia. Schizophr Res.

15. Wray NR, Ripke S, Mattheisen M, Trzaskowski M, Byrne EM, Abdellaoui A, et al. (2018): Genome-wide association analyses identify 44 risk variants and refine the genetic architecture of major depression. Nat Genet. 50:668-681.

16. Reginsson GW, Ingason A, Euesden J, Bjornsdottir G, Olafsson S, Sigurdsson E, et al. (2018): Polygenic risk scores for schizophrenia and bipolar disorder associate with addiction. Addict Biol. 23:485-492.

17. Mustonen A, Ahokas T, Nordstrom T, Murray GK, Maki P, Jaaskelainen E, et al. (2018): Smokin' hot: adolescent smoking and the risk of psychosis. Acta Psychiatr Scand. 138:5-14.

18. Fergusson DM, Goodwin RD, Horwood LJ (2003): Major depression and cigarette smoking: results of a 21-year longitudinal study. Psychol Med. 33:1357-1367.

19. Chaiton MO, Cohen JE, O'Loughlin J, Rehm J (2009): A systematic review of longitudinal studies on the association between depression and smoking in adolescents. $B M C$ Public Health. 9:356. 
medRxiv preprint doi: https://doi.org/10.1101/2020.02.07.20021089; this version posted February 9, 2020. The copyright holder for this preprint (which was not certified by peer review) is the author/funder, who has granted medRxiv a license to display the preprint in It is made available under a CC-BY-NC-ND 4.0 International license .

20. Diaz FJ, James D, Botts S, Maw L, Susce MT, de Leon J (2009): Tobacco smoking behaviors in bipolar disorder: a comparison of the general population, schizophrenia, and major depression. Bipolar Disord. 11:154-165.

21. Gurillo P, Jauhar S, Murray RM, MacCabe JH (2015): Does tobacco use cause psychosis? Systematic review and meta-analysis. Lancet Psychiatry. 2:718-725.

22. Wood AP, Dawe S, Gullo MJ (2013): The role of personality, family influences, and prosocial risk-taking behavior on substance use in early adolescence. J Adolesc. 36:871-881.

23. Gullo MJ, Dawe S (2008): Impulsivity and adolescent substance use: rashly dismissed as "all-bad"? Neurosci Biobehav Rev. 32:1507-1518.

24. Reddy LF, Lee J, Davis MC, Altshuler L, Glahn DC, Miklowitz DJ, et al. (2014): Impulsivity and risk taking in bipolar disorder and schizophrenia. Neuropsychopharmacology. 39:456-463.

25. Hammerschlag AR, Stringer S, de Leeuw CA, Sniekers S, Taskesen E, Watanabe K, et al. (2017): Genome-wide association analysis of insomnia complaints identifies risk genes and genetic overlap with psychiatric and metabolic traits. Nat Genet. 49:1584-1592.

26. Clifton EAD, Perry JRB, Imamura F, Lotta LA, Brage S, Forouhi NG, et al. (2018): Genome-wide association study for risk taking propensity indicates shared pathways with body mass index. Commun Biol. 1:36.

27. Nivard MG, Verweij KJH, Minică CC, Treur JL, International Cannabis Consortium, Derks EM, et al. (2016): Connecting the dots, genome-wide association studies in substance use. Mol Psychiatry. 21:733.

28. Walters RK, Polimanti R, Johnson EC, McClintick JN, Adams MJ, Adkins AE, et al. (2018): Transancestral GWAS of alcohol dependence reveals common genetic underpinnings with psychiatric disorders. Nat Neurosci. 21:1656-1669.

29. Taylor MJ, Gregory AM, Freeman D, Ronald A (2015): Do sleep disturbances and psychotic-like experiences in adolescence share genetic and environmental influences? $J$ Abnorm Psychol. 124:674-684. 
medRxiv preprint doi: https://doi.org/10.1101/2020.02.07.20021089; this version posted February 9, 2020. The copyright holder for this preprint (which was not certified by peer review) is the author/funder, who has granted medRxiv a license to display the preprint in It is made available under a CC-BY-NC-ND 4.0 International license .

30. Pasman JA, Verweij KJH, Gerring Z, Stringer S, Sanchez-Roige S, Treur JL, et al. (2018): GWAS of lifetime cannabis use reveals new risk loci, genetic overlap with psychiatric traits, and a causal influence of schizophrenia. Nat Neurosci. 21:1161-1170.

31. Vermeulen J, Wootton RE, Treur JL, Sallis HM, Jones HJ, Zammit S, et al. (2019): Smoking and the risk for bipolar disorder: evidence from a bidirectional Mendelian randomisation study. Br J Psychiatry.1-7.

32. Wootton RE, Richmond RC, Stuijfzand BG, Lawn RB, Sallis HM, Taylor GMJ, et al. (2019): Evidence for causal effects of lifetime smoking on risk for depression and schizophrenia: a Mendelian randomisation study. Psychol Med.1-9.

33. Wolfe RM, Reeves LE, Gibson LE, Cooper S, Ellman LM (2017): Attenuated positive psychotic symptoms in relation to cigarette smoking in a nonclinical population. Nicotine Tob Res. 19:124-128.

34. Mallet J, Mazer N, Dubertret C, Le Strat Y (2018): Tobacco Smoking and PsychoticLike Experiences in a General Population Sample. J Clin Psychiatry. 79.

35. van Gastel WA, MacCabe JH, Schubart CD, Vreeker A, Tempelaar W, Kahn RS, et al. (2013): Cigarette smoking and cannabis use are equally strongly associated with psychoticlike experiences: a cross-sectional study in 1929 young adults. Psychol Med. 43:2393-2401. 36. Saha S, Scott JG, Varghese D, Degenhardt L, Slade T, McGrath JJ (2011): The association between delusional-like experiences, and tobacco, alcohol or cannabis use: a nationwide population-based survey. BMC Psychiatry. 11:202.

37. McGrath JJ, Alati R, Clavarino A, Williams GM, Bor W, Najman JM, et al. (2016): Age at first tobacco use and risk of subsequent psychosis-related outcomes: A birth cohort study. Aust N Z J Psychiatry. 50:577-583.

38. Koyanagi A, Stickley A, Haro JM (2016): Psychotic symptoms and smoking in 44 countries. Acta Psychiatr Scand. 133:497-505.

39. Davies J, Sullivan S, Zammit S (2018): Adverse life outcomes associated with adolescent psychotic experiences and depressive symptoms. Soc Psychiatry Psychiatr Epidemiol. 53:497-507. 
medRxiv preprint doi: https://doi.org/10.1101/2020.02.07.20021089; this version posted February 9, 2020. The copyright holder for this preprint (which was not certified by peer review) is the author/funder, who has granted medRxiv a license to display the preprint in It is made available under a CC-BY-NC-ND 4.0 International license .

40. Ferdinand RF, van der Ende J, Verhulst FC (2004): Associations between visual and auditory hallucinations in children and adolescents, and tobacco use in adulthood. Soc Psychiatry Psychiatr Epidemiol. 39:514-520.

41. Vermeulen J, Schirmbeck F, Blankers M, van Tricht M, van den Brink W, de Haan L (2019): Smoking, symptoms, and quality of life in patients with psychosis, siblings, and healthy controls: a prospective, longitudinal cohort study. Lancet Psychiatry. 6:25-34. 42. Liu M, Jiang Y, Wedow R, Li Y, Brazel DM, Chen F, et al. (2019): Association studies of up to 1.2 million individuals yield new insights into the genetic etiology of tobacco and alcohol use. Nat Genet. 51:237-244.

43. Pain O, Dudbridge F, Cardno AG, Freeman D, Lu Y, Lundstrom S, et al. (2018): Genome-wide analysis of adolescent psychotic-like experiences shows genetic overlap with psychiatric disorders. Am J Med Genet B Neuropsychiatr Genet. 177:416-425.

44. Haworth CM, Davis OS, Plomin R (2013): Twins Early Development Study (TEDS): a genetically sensitive investigation of cognitive and behavioral development from childhood to young adulthood. Twin Res Hum Genet. 16:117-125.

45. Boyd A, Golding J, Macleod J, Lawlor DA, Fraser A, Henderson J, et al. (2013): Cohort Profile: the 'children of the 90s'--the index offspring of the Avon Longitudinal Study of Parents and Children. Int J Epidemiol. 42:111-127.

46. Fraser A, Macdonald-Wallis C, Tilling K, Boyd A, Golding J, Davey Smith G, et al. (2013): Cohort Profile: the Avon Longitudinal Study of Parents and Children: ALSPAC mothers cohort. Int J Epidemiol. 42:97-110.

47. Anckarsater H, Lundstrom S, Kollberg L, Kerekes N, Palm C, Carlstrom E, et al. (2011): The Child and Adolescent Twin Study in Sweden (CATSS). Twin Res Hum Genet. 14:495-508.

48. Haapea M, Miettunen J, Laara E, Joukamaa MI, Jarvelin MR, Isohanni MK, et al. (2008): Non-participation in a field survey with respect to psychiatric disorders. Scand J Public Health. 36:728-736. 
medRxiv preprint doi: https://doi.org/10.1101/2020.02.07.20021089; this version posted February 9, 2020. The copyright holder for this preprint (which was not certified by peer review) is the author/funder, who has granted medRxiv a license to display the preprint in It is made available under a CC-BY-NC-ND 4.0 International license .

49. Ortega-Alonso A, Ekelund J, Sarin AP, Miettunen J, Veijola J, Jarvelin MR, et al. (2017): Genome-Wide Association Study of Psychosis Proneness in the Finnish Population. Schizophr Bull. 43:1304-1314.

50. Chapman LJ, Chapman JP, Raulin ML (1978): Body-image aberration in Schizophrenia. J Abnorm Psychol. 87:399-407.

51. Eckblad M, Chapman LJ (1986): Development and validation of a scale for hypomanic personality. J Abnorm Psychol. 95:214-222.

52. Chapman LJ, Chapman JP, Raulin ML (1976): Scales for physical and social anhedonia. J Abnorm Psychol. 85:374-382.

53. Schizophrenia Working Group of the Psychiatric Genomics Consortium (2014): Biological insights from 108 schizophrenia-associated genetic loci. Nature. 511:421-427. 54. Bipolar Disorder and Schizophrenia Working Group of the Psychiatric Genomics Consortium (2018): Genomic Dissection of Bipolar Disorder and Schizophrenia, Including 28 Subphenotypes. Cell. 173:1705-1715.e1716.

55. Bulik-Sullivan B, Finucane HK, Anttila V, Gusev A, Day FR, Loh PR, et al. (2015): An atlas of genetic correlations across human diseases and traits. Nat Genet. 47:1236-1241.

56. Bulik-Sullivan B, Loh PR, Finucane HK, Ripke S, Yang J, Patterson N, et al. (2015): LD Score regression distinguishes confounding from polygenicity in genome-wide association studies. Nat Genet. 47:291-295.

57. Merikangas KR, Jin R, He JP, Kessler RC, Lee S, Sampson NA, et al. (2011): Prevalence and correlates of bipolar spectrum disorder in the world mental health survey initiative. Arch Gen Psychiatry. 68:241-251.

58. Moreno-Kustner B, Martin C, Pastor L (2018): Prevalence of psychotic disorders and its association with methodological issues. A systematic review and meta-analyses. PLoS One. 13:e0195687.

59. Lim GY, Tam WW, Lu Y, Ho CS, Zhang MW, Ho RC (2018): Prevalence of Depression in the Community from 30 Countries between 1994 and 2014. Sci Rep. 8:2861. 
medRxiv preprint doi: https://doi.org/10.1101/2020.02.07.20021089; this version posted February 9, 2020. The copyright holder for this preprint (which was not certified by peer review) is the author/funder, who has granted medRxiv a license to display the preprint in It is made available under a CC-BY-NC-ND 4.0 International license .

60. Grotzinger AD, Rhemtulla M, de Vlaming R, Ritchie SJ, Mallard TT, Hill WD, et al. (2019): Genomic structural equation modelling provides insights into the multivariate genetic architecture of complex traits. Nat Hum Behav. 3:513-525.

61. R Core Team (2018): R: A Language and Environment for Statistical Computing. Vienna, Austria: R Foundation for Statistical Computing.

62. Davey Smith G, Ebrahim S (2003): 'Mendelian randomization': can genetic epidemiology contribute to understanding environmental determinants of disease? Int $J$ Epidemiol. 32:1-22.

63. Zhu Z, Zheng Z, Zhang F, Wu Y, Trzaskowski M, Maier R, et al. (2018): Causal associations between risk factors and common diseases inferred from GWAS summary data. Nat Commun. 9:224.

64. Bowden J, Davey Smith G, Burgess S (2015): Mendelian randomization with invalid instruments: effect estimation and bias detection through Egger regression. Int J Epidemiol. 44:512-525.

65. Bowden J, Davey Smith G, Haycock PC, Burgess S (2016): Consistent Estimation in Mendelian Randomization with Some Invalid Instruments Using a Weighted Median Estimator. Genet Epidemiol. 40:304-314.

66. Hartwig FP, Davey Smith G, Bowden J (2017): Robust inference in summary data Mendelian randomization via the zero modal pleiotropy assumption. Int J Epidemiol. 46:1985-1998.

67. Stahl EA, Breen G, Forstner AJ, McQuillin A, Ripke S, Trubetskoy V, et al. (2019): Genome-wide association study identifies 30 loci associated with bipolar disorder. Nat Genet. 51:793-803.

68. Chang CC, Chow CC, Tellier LC, Vattikuti S, Purcell SM, Lee JJ (2015): Secondgeneration PLINK: rising to the challenge of larger and richer datasets. Gigascience. 4:7. 69. Hemani G, Zheng J, Elsworth B, Wade KH, Haberland V, Baird D, et al. (2018): The MR-Base platform supports systematic causal inference across the human phenome. Elife. 7. 
medRxiv preprint doi: https://doi.org/10.1101/2020.02.07.20021089; this version posted February 9, 2020. The copyright holder for this preprint (which was not certified by peer review) is the author/funder, who has granted medRxiv a license to display the preprint in It is made available under a CC-BY-NC-ND 4.0 International license .

70. Yang J, Lee SH, Goddard ME, Visscher PM (2011): GCTA: a tool for genome-wide complex trait analysis. Am J Hum Genet. 88:76-82.

71. Thorgeirsson TE, Geller F, Sulem P, Rafnar T, Wiste A, Magnusson KP, et al. (2008): A variant associated with nicotine dependence, lung cancer and peripheral arterial disease. Nature. 452:638-642.

72. Erzurumluoglu AM, Liu M, Jackson VE, Barnes DR, Datta G, Melbourne CA, et al. (2019): Meta-analysis of up to 622,409 individuals identifies 40 novel smoking behaviour associated genetic loci. Mol Psychiatry.

73. Tobacco and Genetics Consortium (2010): Genome-wide meta-analyses identify multiple loci associated with smoking behavior. Nat Genet. 42:441-447.

74. McKinney DL, Vansickel AR (2016): Chapter 9 - Nicotine Chemistry, Pharmacology, and Pharmacokinetics. In: Preedy VR, editor. Neuropathology of Drug Addictions and Substance Misuse. San Diego: Academic Press, pp 93-103.

75. Levin ED (2018): Chapter Six - Chronic Nicotine Effects on Memory and Nicotine Self-Administration: Age of Exposure is Key. In: Aschner M, Costa LG, editors. Advances in Neurotoxicology: Academic Press, pp 189-196.

76. McCallum SE, Cowe MA, Lewis SW, Glick SD (2012): alpha3beta4 nicotinic acetylcholine receptors in the medial habenula modulate the mesolimbic dopaminergic response to acute nicotine in vivo. Neuropharmacology. 63:434-440.

77. Brody AL, Olmstead RE, London ED, Farahi J, Meyer JH, Grossman P, et al. (2004): Smoking-induced ventral striatum dopamine release. Am J Psychiatry. 161:1211-1218. 78. Ashok AH, Mizuno Y, Howes OD (2019): Tobacco smoking and dopaminergic function in humans: a meta-analysis of molecular imaging studies. Psychopharmacology. 236:1119-1129.

79. Coyle JT (2006): Glutamate and schizophrenia: beyond the dopamine hypothesis. Cell Mol Neurobiol. 26:365-384.

80. Mineur YS, Picciotto MR (2009): Biological basis for the co-morbidity between smoking and mood disorders. J Dual Diagn. 5:122-130. 
medRxiv preprint doi: https://doi.org/10.1101/2020.02.07.20021089; this version posted February 9, 2020. The copyright holder for this preprint (which was not certified by peer review) is the author/funder, who has granted medRxiv a license to display the preprint in It is made available under a CC-BY-NC-ND 4.0 International license .

81. Jobson CLM, Renard J, Szkudlarek H, Rosen LG, Pereira B, Wright DJ, et al. (2019): Adolescent Nicotine Exposure Induces Dysregulation of Mesocorticolimbic Activity States and Depressive and Anxiety-like Prefrontal Cortical Molecular Phenotypes Persisting into Adulthood. Cereb Cortex. 29:3140-3153.

82. Quigley H, MacCabe JH (2019): The relationship between nicotine and psychosis. Ther Adv Psychopharmacol. 9:2045125319859969.

83. Newbury JB, Arseneault L, Beevers S, Kitwiroon N, Roberts S, Pariante CM, et al. (2019): Association of Air Pollution Exposure With Psychotic Experiences During Adolescence. JAMA Psychiatry. 76:614-623.

84. Poulton R, Caspi A, Moffitt TE, Cannon M, Murray R, Harrington H (2000): Children's self-reported psychotic symptoms and adult schizophreniform disorder: a 15-year longitudinal study. Arch Gen Psychiatry. 57:1053-1058.

85. Welham J, Scott J, Williams G, Najman J, Bor W, O'Callaghan M, et al. (2009): Emotional and behavioural antecedents of young adults who screen positive for non-affective psychosis: a 21-year birth cohort study. Psychol Med. 39:625-634.

86. Hanssen M, Bak M, Bijl R, Vollebergh W, van Os J (2005): The incidence and outcome of subclinical psychotic experiences in the general population. Br J Clin Psychol. $44: 181-191$.

87. Werbeloff N, Drukker M, Dohrenwend BP, Levav I, Yoffe R, van Os J, et al. (2012): Self-reported attenuated psychotic symptoms as forerunners of severe mental disorders later in life. Arch Gen Psychiatry. 69:467-475.

88. Zammit S, Kounali D, Cannon M, David AS, Gunnell D, Heron J, et al. (2013): Psychotic experiences and psychotic disorders at age 18 in relation to psychotic experiences at age 12 in a longitudinal population-based cohort study. Am J Psychiatry. 170:742-750.

89. Dominguez MD, Wichers M, Lieb R, Wittchen HU, van Os J (2011): Evidence that onset of clinical psychosis is an outcome of progressively more persistent subclinical psychotic experiences: an 8-year cohort study. Schizophr Bull. 37:84-93. 
medRxiv preprint doi: https://doi.org/10.1101/2020.02.07.20021089; this version posted February 9, 2020. The copyright holder for this preprint (which was not certified by peer review) is the author/funder, who has granted medRxiv a license to display the preprint in It is made available under a CC-BY-NC-ND 4.0 International license .

90. Barkhuizen W, Pain O, Dudbridge F, Ronald A (2019): Genetic overlap between psychotic experiences in the community across age and with psychiatric disorders.

bioRxiv.718015. 